\title{
Role of newly formed platelets in thrombus formation in rat after clopidogrel treatment: comparison to the reversible binding P2Y(12) antagonist ticagrelor
}

Citation for published version (APA):

Kuijpers, M. J. E., Megens, R. T. A., Nikookhesal, E., Feijge, M. A. H., De Mey, J. G. R., Egbrink, M. G. A. O., van Giezen, J. J. J., \& Heemskerk, J. W. M. (2011). Role of newly formed platelets in thrombus formation in rat after clopidogrel treatment: comparison to the reversible binding P2Y(12) antagonist ticagrelor. Thrombosis and Haemostasis, 106(6), 1179-1188. https://doi.org/10.1160/TH11-04-0252

Document status and date:

Published: 01/12/2011

DOI:

10.1160/TH11-04-0252

Document Version:

Publisher's PDF, also known as Version of record

Document license:

Taverne

Please check the document version of this publication:

- A submitted manuscript is the version of the article upon submission and before peer-review. There can be important differences between the submitted version and the official published version of record.

People interested in the research are advised to contact the author for the final version of the publication, or visit the DOI to the publisher's website.

- The final author version and the galley proof are versions of the publication after peer review.

- The final published version features the final layout of the paper including the volume, issue and page numbers.

Link to publication

\footnotetext{
General rights rights.

- You may freely distribute the URL identifying the publication in the public portal. please follow below link for the End User Agreement:

www.umlib.nl/taverne-license

Take down policy

If you believe that this document breaches copyright please contact us at:

repository@maastrichtuniversity.nl

providing details and we will investigate your claim.
}

Copyright and moral rights for the publications made accessible in the public portal are retained by the authors and/or other copyright owners and it is a condition of accessing publications that users recognise and abide by the legal requirements associated with these

- Users may download and print one copy of any publication from the public portal for the purpose of private study or research.

- You may not further distribute the material or use it for any profit-making activity or commercial gain

If the publication is distributed under the terms of Article $25 \mathrm{fa}$ of the Dutch Copyright Act, indicated by the "Taverne" license above, 


\title{
Role of newly formed platelets in thrombus formation in rat after clopidogrel treatment: comparison to the reversible binding $\mathrm{P}_{2} \mathrm{Y}_{12}$ antagonist ticagrelor
}

\author{
Marijke J. E. Kuijpers'; Remco T. A. Megens ${ }^{4}$; Elham Nikookhesal'5; Marion A. H. Feijge'; J. G. R. De Mey²; \\ Mirjam G. A. oude Egbrink ${ }^{3}$; J. J. J. van Giezen ${ }^{5}$; Johan W. M. Heemskerk ${ }^{1}$ \\ ${ }^{1}$ Department of Biochemistry, Cardiovascular Research Institute Maastricht, Maastricht University, Maastricht, the Netherlands; ${ }^{2}$ Department of Pharmacology, Cardiovascular \\ Research Institute Maastricht, Maastricht University, Maastricht, the Netherlands; ${ }^{3}$ Department of Physiology, Cardiovascular Research Institute Maastricht, Maastricht University, \\ Maastricht, the Netherlands; ${ }^{4}$ Institute for Cardiovascular Prevention, Ludwig-Maximilians-University Munich, Munich, Germany; ${ }^{5}$ AstraZeneca R\&D, Mölndal, Sweden
}

\begin{abstract}
Summary
Platelet P2 $\mathrm{Y}_{12}$ receptors play an important role in arterial thrombosis by stimulating thrombus growth. Both irreversibly (clopidogrel) and re-

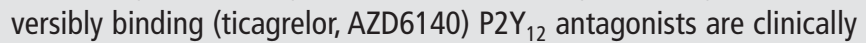
used for restricted periods, but possible differences in platelet function recovery after drug cessation have not been investigated. We treated WKY rats with a single, high dose of $200 \mathrm{mg} / \mathrm{kg}$ clopidogrel or $40 \mathrm{mg} /$ $\mathrm{kg}$ ticagrelor. Blood was collected at different time points after treatment. Flow cytometry confirmed full platelet protection against ADP-induced $\alpha_{\| l} \beta_{3}$ activation shortly after clopidogrel or ticagrelor treatment. At later time points after clopidogrel treatment, a subpopulation of juvenile platelets appeared that was fully responsive to ADP. Addition of ticagrelor to clopidogrel-treated blood reduced $\alpha_{\| l b} \beta_{3}$ activation of the unprotected platelets. In contrast, at later time points after ticagrelor treatment, all platelets gradually lost their protection against ADP activation. Perfusion experiments showed abolishment of thrombus
\end{abstract}

Correspondence to:

Dr. M. J. E. Kuijpers

Dept. of Biochemistry

CARIM, Maastricht University

P.O. Box 616

6200 MD Maastricht, the Netherlands

Tel.: +31 43 3881537, Fax: +31 433884159

E-mail: Marijke.Kuijpers@maastrichtuniversity.nl formation shortly after clopidogrel or ticagrelor treatment. Thrombus formation on collagen was determined under high shear flow conditions. At later time points, large thrombi formed in the clopidogrel but not in the ticagrelor group, and unprotected, juvenile platelets preferentially incorporated into the formed thrombi. However, platelets from both groups were still similarly reduced in assays of whole blood aggregation. Conclusively, recovery of rat platelet function after ticagrelor differs mechanistically from that after clopidogrel. This difference is masked by conventional platelet aggregation methods, but is revealed by thrombus formation measurement under flow. Juvenile platelets formed at later time points after clopidogrel treatment promoted thrombus formation.

\section{Keywords}

Platelet physiology, arterial thrombosis, ADP receptors, pharmacodynamics

Received: April 20, 2011

Accepted after major revision: September 12, 2011

Prepublished online: November 10, 2011

doi:10.1160/TH11-04-0252

Thromb Haemost 2011; 106: 1179-1188

\section{Introduction}

Both clinical trials and experimental animal studies have shown that interaction of the platelet $\mathrm{P} 2 \mathrm{Y}_{12}$ receptor with autocrine adenosine diphosphate (ADP) plays an important role in arterial thrombogenesis (1-3). In various clinical settings, the thienopyridine prodrug clopidogrel, inhibiting $\mathrm{P}_{2} \mathrm{Y}_{12}$-dependent platelet activation, effectively reduces the occurrence of cardiovascular events $(4,5)$. The action mechanism of clopidogrel depends upon its metabolism by cytochrome $\mathrm{P} 450$ proteins (6) and possibly paraoxonase-1 (7), causing formation of an active metabolite, which irreversibly binds to the $\mathrm{P} 2 \mathrm{Y}_{12}$ receptors. Once modified, the $\mathrm{P} 2 \mathrm{Y}_{12}$ receptors are dysfunctional for the remaining life-span of a platelet. Blood plasma exposure to the active metabolite occurs during approximately 6 hours (h) after dosing (8), meaning that new platelets generated at later time points will have unprotected $\mathrm{P} 2 \mathrm{Y}_{12}$ re- ceptors. Besides the known inter-donor variation in prodrug conversion, this may explain the variable degree of inhibition reported in platelets from clopidogrel-treated patients $(3,9,10)$. Recent studies point to the possibility that cessation of clopidogrel intake leads to recurrent adverse effects $(11,12)$. Whether or not this is related to the inhibition mechanism of clopidogrel as an irreversible receptor antagonist, halting its action during drug recovery, is unknown.

Ticagrelor (AZD6140) is a directly acting, reversibly binding, orally available $\mathrm{P} 2 \mathrm{Y}_{12}$ antagonist, which belongs to a new class of cyclopentyl-triazolo pyrimidines (13). In contrast to the thienopyridine compounds clopidogrel and prasugrel, it does not need to be converted metabolically and it binds reversibly to the $\mathrm{P} 2 \mathrm{Y}_{12}$ receptors. Ticagrelor has been shown to achieve greater and more consistent levels of platelet inhibition than clopidogrel (14-17). In the phase III trial, PLATO, this translated into a significantly re- 
duced rate of myocardial infarction, stroke or death from vascular causes, without increase in the rate of overall major bleeding as compared with clopidogrel (15). A recent study shows that ticagrelor therapy overcomes the non-responsiveness in patients to clopidogrel, while providing 24-h duration of platelet inhibition (16). The implication of reversible binding of ticagrelor to $\mathrm{P}_{2} \mathrm{Y}_{12}$ is that the extent of platelet inhibition is directly related to the drug level in the blood (18). As a result, all platelets, including the new ones formed after ticagrelor administration, are expected to interact with the drug and become inhibited at a similar degree.

In this paper, we studied the effect of treatment of rats with a single high dose of clopidogrel or ticagrelor on ADP-induced integrin $\alpha_{\text {IIb }} \beta_{3}$ activation and platelet aggregation at different time points after drug exposure. In addition, we measured the effects of these drugs on collagen-induced thrombus formation under physiologically relevant conditions of high shear blood flow, which process relies on autocrine ADP-mediated platelet activation via the $\mathrm{P} 2 \mathrm{Y}_{12}$ receptors $(19,20)$. The results point to a marked, stimulating effect of newly formed, juvenile platelets after the intake of clopidogrel on thrombus formation under flow.

\section{Materials and methods}

\section{$\mathrm{P}_{2} \mathrm{Y}_{12}$ receptor antagonists}

Clopidogrel (99.1\%, Sequoia Research Products, Berkshire, UK) was dissolved in saline for oral administration in rats. Ticagrelor (AZD6140) was synthesised by AstraZeneca R\&D (Mölndal, Sweden). For oral administration, it was prepared as a nanosuspension in 5\% mannitol (21).

\section{Animals}

Experiments were approved by the local experimental care and use committee. Procedures were in accordance with the local guidelines for laboratory animal experiments. Female WKY rats were used at $3-5$ months of age ( $275 \pm 25 \mathrm{~g})$. Antagonists were administered orally at a concentration resulting in full inhibition of $\mathrm{P}_{2} \mathrm{Y}_{12}$-induced platelet aggregation $(22,23)$, i.e. clopidogrel at 200 $\mathrm{mg} / \mathrm{kg}$ (solution of $50 \mathrm{mg} / \mathrm{ml}$ ) and ticagrelor at $40 \mathrm{mg} / \mathrm{kg}(10 \mathrm{mg} /$ $\mathrm{ml}$ ). Saline (equivalent volume) was given as control. At predetermined time points after administration (clopidogrel: 24, 48 or 72 h; ticagrelor: 4,18 , or $48 \mathrm{~h}$ ), rats were anaesthetised by ventilation with isoflurane, and bled by abdominal aorta puncture. As the platelet turnover in rodents is 3-5 days (24), blood was collected till 72 $\mathrm{h}$ after drug administration.

\section{Preparation of blood and platelet samples}

Blood was collected (final concentration) into either $12.9 \mathrm{mM}$ trisodium citrate or $50 \mu \mathrm{M}$ PPACK (Merck, Stockholm, Sweden) plus $5 \mathrm{U} / \mathrm{ml}$ fragmin (Pfizer, Sollentuna, Sweden). In the latter case, additional $10 \mu \mathrm{M}$ PPACK was added after $1 \mathrm{~h}$. Platelet-rich plasma (PRP) was prepared from citrate-anticoagulated blood by centrifugation (5 minutes [min] at $240 \mathrm{~g}$ ). Platelet-poor plasma was obtained by centrifugation at 1,500 g for $15 \mathrm{~min}$. Platelet count was determined with a Sysmex KX21 whole blood cell counter (Hamburg, Germany). Samples were used within $3 \mathrm{~h}$ of blood collection (platelet counts $>400 \times 10^{9} / 1$ ). After $\mathrm{P}_{2} \mathrm{Y}_{12}$ inhibitor administration, PPACK-anticoagulated blood from the same rats was divided in samples for whole blood aggregation and flow perfusion experiments, to enable a direct comparison of the results.

\section{Flow cytometry}

Citrate-anticoagulated PRP was diluted 1:10 with modified Tyrode buffer $(137 \mathrm{mM}, \mathrm{NaCl}, 2.8 \mathrm{mM} \mathrm{KCl}, 1 \mathrm{mM} \mathrm{MgCl}, 12 \mathrm{mM}$ $\mathrm{NaHCO}_{3}, 0.4 \mathrm{mM} \mathrm{Na}_{2} \mathrm{HPO}_{4}, 0.35 \%$ BSA, 10 mM HEPES, $5.5 \mathrm{mM}$ glucose, $\mathrm{pH}$ 7.4) and mixed with OG488-labelled human fibrinogen (1:30, Invitrogen, Leiden, the Netherlands). After 10 min of activation with $20 \mu \mathrm{M}$ 2-methylthioadenosine 5 '-diphosphate (2MeSADP, a stable ADP analogue), samples were analysed by flow cytometry using a FACS Calibur flow cytometer and CellQuest software (Becton and Dickinson, Palo Alto, CA, USA). Alternatively, samples were analysed with an Accuri C6 flow cytometer (Ann Arbor, MI, USA). Per sample, 10,000 events (platelets) were acquired for analysis. Samples were run in duplicate.

\section{Platelet aggregation in whole blood}

Whole blood aggregation measurements were performed with a Multiplate impedance aggregometer (Dynabyte Medical, Munich, Germany), as described (25). Blood samples were allowed to rest for $1 \mathrm{~h}$ at $37^{\circ} \mathrm{C}$. Per experiment, $300 \mu \mathrm{l}$ of PPACK-anticoagulated blood was diluted with $300 \mu \mathrm{l}$ saline, and incubated at $37^{\circ} \mathrm{C}$ under stirring ( $800 \mathrm{rpm}$ ). After $2 \mathrm{~min}, 6.4 \mu \mathrm{M}$ ADP was added (Dynabyte Medical). The extent of platelet aggregation was assessed from the area under the impedance curve $(6 \mathrm{~min})$. Other blood samples were similarly stimulated with $6.4 \mu \mathrm{M}$ ADP, and analysed for changes in single platelet count $(10 \mu \mathrm{l}$ samples before and after stimulation) (26). Samples were added to a 96 -well plate, containing per well $200 \mu$ fixative (1\% paraformaldehyde in phosphatebuffered saline), and further diluted. Platelet count was measured in duplicate using a FACS array Bioanalyser system (Becton and Dickinson) using numbers of red blood cells as internal control. Light transmission aggregometry of platelets in PRP was performed as described (27). 


\section{Thrombus formation under arterial flow conditions}

Washed glass coverslips were coated with type I collagen Horm (200 $\mu \mathrm{g} \mathrm{ml;} \mathrm{Nycomed,} \mathrm{Linz,} \mathrm{Austria),} \mathrm{and} \mathrm{blocked} \mathrm{with} \mathrm{Tyrode}$ hepes buffer (136 mM NaCl, $2.7 \mathrm{mM} \mathrm{KCl}, 0.42 \mathrm{mM} \mathrm{NaH}_{2} \mathrm{PO}_{4}, 5$ $\mathrm{mM}$ Hepes, $2 \mathrm{mM} \mathrm{MgCl}_{2}$ and $0.1 \%$ glucose) containing $1 \%$ bovine serum albumin (BSA). Coated coverslips were mounted in a parallel plate flow chamber. Microscopic phase contrast and fluorescence images were recorded with a Zeiss axioscope microscope (Carl Zeiss, Göttingen, Germany), equipped with a 40X oil objective and a C9100-13 EM-CCD camera (Hamamatsu Photonics, Solna, Sweden). PPACK-anticoagulated blood was perfused through the flow chamber at a shear rate of $1,000 \mathrm{~s}^{-1}$ using an AL2000 programmable syringe pump (WPI, Stevenage, UK). Where indicated, $20 \%$ washed platelets from rats were pre-labelled with carboxy fluorescein diacetate succinimidyl ester (CFSE, $6 \mu \mathrm{M})(27)$, and then added to the blood. After 4 min perfusion, followed by rinsing with Tyrode Hepes (supplemented with $0.1 \%$ $\mathrm{BSA}, 2 \mathrm{mM} \mathrm{CaCl}_{2}$ and $1 \mathrm{U} / \mathrm{ml}$ heparin), fluorescence and phasecontrast images were taken from the optical plane of the collagen surface. Where indicated, images of CFSE fluorescence were captured in real time during flow using a Zeiss LSM7 confocal system (Jena, Germany).

\section{Image analysis}

Microscopic images were analysed using Zeiss axiovision 4.6.3, Image J or Metamorph software (MDS Analytical Technologies, Downingtown, PA, USA). Total surface area covered by platelet aggregates as well as sizes of the aggregates were determined semiautomatically from $>10$ images. A segmentation threshold was used, combined with an opening-closing procedure for detection of the boundaries between individual features.

\section{Statistical analysis}

Data are presented as means \pm standard error (SE). Significance of differences between groups was determined with the non-parametric Mann-Whitney U test. Statistical analyses were performed using SPSS 16.0 (Chicago, IL, USA).

\section{Results}

\section{Effect of short-term clopidogrel or ticagrelor treat- ment on ADP receptor-induced platelet activation}

We first tested a sensitive method to compare effects of the irreversible $\mathrm{P}_{2} \mathrm{Y}_{12}$ antagonist, clopidogrel, and the reversibly binding $\mathrm{P}_{2} \mathrm{Y}_{12}$ antagonist, ticagrelor, on the responses of rat platelets. Flow cyto- metry was used to determine integrin $\alpha_{\mathrm{II}} \beta_{3}$ activation by analysis of the binding of OG488-fibrinogen to rat platelets in PRP. Control experiments showed that the stable ADP analogue, 2MeSADP, at a concentration of $20 \mu \mathrm{M}$, caused a potent increase in mean fluorescence, with $80 \%$ of the platelets assigned as fibrinogen-binding ( Fig. 1A). Ticagrelor added in vitro at $1 \mu \mathrm{M}$ completely antagonised the OG488-fibrinogen binding with 2MeSADP, demonstrating the suitability of this method to detect $\mathrm{P}_{2} \mathrm{Y}_{12}$-dependent activation of platelets in plasma.

The same test was used to determine platelet $\mathrm{P} 2 \mathrm{Y}_{12}$ activity after in vivo treatment with either irreversible or reversible $\mathrm{P}_{2} \mathrm{Y}_{12}$ antagonist. Rats were treated with a single, high dose of clopidogrel (200 $\mathrm{mg} / \mathrm{kg}$ ) or ticagrelor $(40 \mathrm{mg} / \mathrm{kg})$. Blood was taken at early time points expected to give full $\mathrm{P}_{2} \mathrm{Y}_{12}$ receptor protection by the active clopidogrel metabolite or by ticagrelor, and also at later time points at which receptor protection was known to be reduced (22). At 24 $\mathrm{h}$ after clopidogrel (see below) or $4 \mathrm{~h}$ after ticagrelor ( Fig. 1B), $2 \mathrm{MeSADP}$ was unable to induce fibrinogen binding to platelets in PRP; in case of ticagrelor only $13 \%$ of the platelets were marked as fibrinogen-binding. Pilot experiments indicated that partial recovery $(-50 \%)$ of ADP-induced platelet aggregation and integrin $\alpha_{\mathrm{IIb}} \beta_{3}$ activation was achieved at $48 \mathrm{~h}$ after clopidogrel and $18 \mathrm{~h}$ after ticagrelor application (data not shown, and Fig 5B). The efficacy of these single dose applications was confirmed by measurement of ADP-induced platelet aggregation in whole blood. After shorter time treatment with clopidogrel $(24 \mathrm{~h})$ or ticagrelor $(4 \mathrm{~h})$, the area under the curve, representing extent and duration of platelet aggregation, was reduced to $4 \pm 2 \%$ and $5 \pm 2 \%$ (mean \pm SE, $n=3$ ), respectively, of the corresponding values for control blood from untreated rats ( Fig. 1C).

\section{Different recovery from inhibition of ADP receptor function after treatment with clopidogrel or ticagrelor}

Subsequently, longer term effects of the single-dose treatment with clopidogrel $(200 \mathrm{mg} / \mathrm{kg})$ or ticagrelor $(40 \mathrm{mg} / \mathrm{kg})$ were investigated. Flow cytometric analysis indicated that at $48 \mathrm{~h}$ after clopidogrel a platelet subpopulation appeared that was fully responsive to 2MeSADP in terms of fibrinogen binding and thus $\alpha_{\mathrm{II}} \beta_{3}$ activation ( Fig. 2A). The numbers of responsive platelets gradually increased to $62 \%$ after $72 \mathrm{~h}$ ( Fig. 2B). In contrast, at longer times after ticagrelor treatment (24-48 h), a separation of 2MeSADP responsive and non-responsive platelets was not seen ( Fig. 2C). Instead, the mean fibrinogen binding of the whole population of platelets increased with the time post dosing ( Fig. 2D). These results suggested that after clopidogrel treatment a new subpopulation of platelets was formed which was fully responsive to $\mathrm{P} 2 \mathrm{Y}_{12}$ receptor stimulation, in contrast to the gradual loss of inhibition of all platelets after ticagrelor treatment.

To further investigate this difference, PRP from clopidogreltreated rats ( $24 \mathrm{~h}$ treatment) was mixed in various ratios with PRP from untreated control rats. Flow cytometric measurement of 


\section{A In vitro}
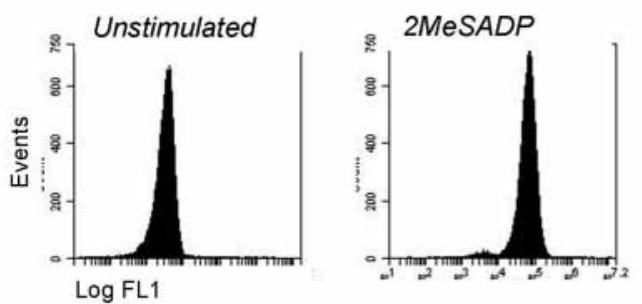

B In vivo
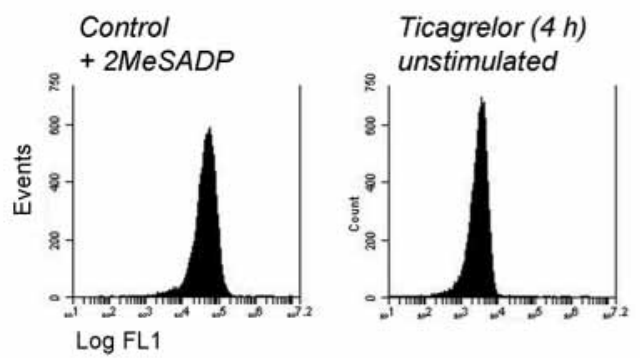

\section{In vivo}

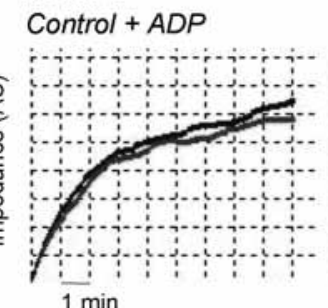

Ticagrelor $(4 h)+A D P$

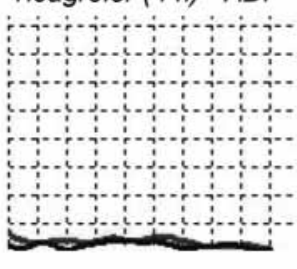

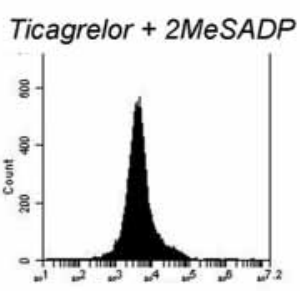

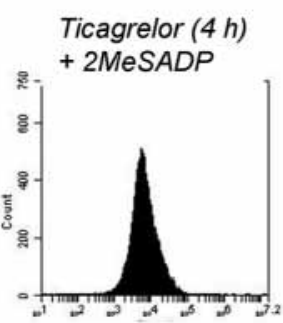

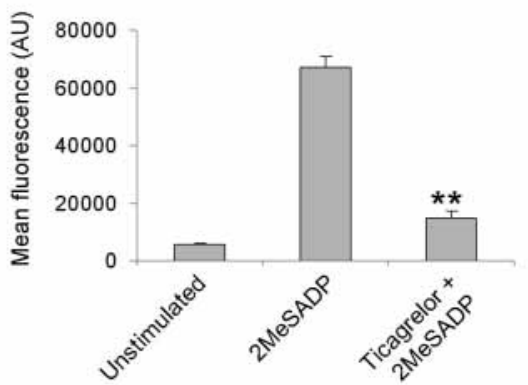

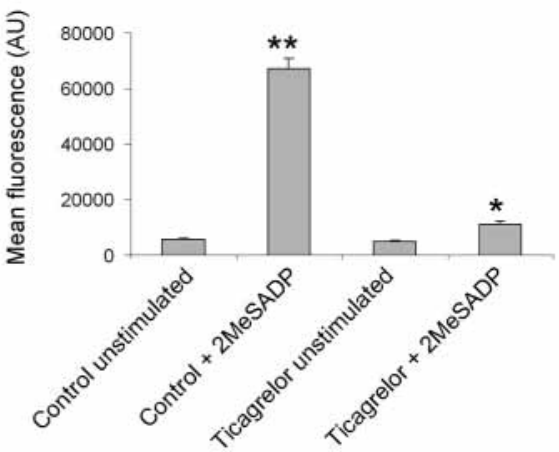

Figure 1: Effect of platelet treatment with ticagrelor in vitro or in vivo on ADP receptor-induced fibrinogen binding and platelet aggregation. A) PRP from control rats was incubated with $1 \mu \mathrm{M}$ ticagrelor, as indicated, and stimulated with $20 \mu \mathrm{M} 2 \mathrm{MeSADP}$ for $10 \mathrm{~min}$. 0G488-fibrinogen binding to platelets was assessed by flow cytometry (mean fluorescence intensity; $\mathrm{AU}$, arbitrary units). $\mathrm{B}, \mathrm{C}$ ) Rats were treated in vivo with vehicle (con- trol), or a single dose of $40 \mathrm{mg} / \mathrm{kg}$ ticagrelor ( $4 \mathrm{~h}$ ) or of $200 \mathrm{mg} / \mathrm{kg}$ clopidogrel (24 h). Whole blood and PRP samples were obtained after indicated times. B) OG488-fibrinogen binding to unstimulated platelets or platelets stimulated 10 min with $20 \mu \mathrm{M} 2 \mathrm{MeSADP}(\mathrm{n}=4-8)$. ${ }^{*} \mathrm{p}<0.05,{ }^{* *} \mathrm{p}<0.001$ vs. no agonist. C) Whole blood aggregation induced by $\operatorname{ADP}(n=3)$. Two representative traces are shown (mean AU of aggregation).
2MeSADP-induced fibrinogen binding showed again two platelet populations, with the platelets from clopidogrel-treated rats being fully protected from integrin activation and the platelets from untreated rats showing high fibrinogen binding $(-$ Fig. $3 \mathrm{~A})$. The fractions of fibrinogen-binding platelets corresponded to the number of untreated control platelets ( Fig. 3B). This indicated that clopidogrel-inactivated platelets were unable to carry over their insensitivity of 2MeSADP-induced integrin activation to untreated platelets. It also confirmed that this flow cytometric method allows identification of the two platelet populations.

In next experiments, the combined effects of ticagrelor and clopidogrel were investigated in rat PRP. Addition of ticagrelor
(30-1,000 nM) to PRP from rats treated with clopidogrel (48 h) resulted in a dose-dependent suppression in 2MeSADP-induced fibrinogen binding, but only in those platelets displaying high fibrinogen binding ( Fig. 4A). Ticagrelor addition to PRP from clopidogrel-treated and control rats suppressed fibrinogen binding in the same concentration range ( Fig. 4B, C). This suggested that the recovery from $\mathrm{P} 2 \mathrm{Y}_{12}$ receptor inhibition after clopidogrel treatment was caused by the appearance of fully unprotected, juvenile platelets, while the recovery after ticagrelor treatment was by a gradually increased responsiveness of the entire platelet population. 
A Clopidogrel + 2MeSADP
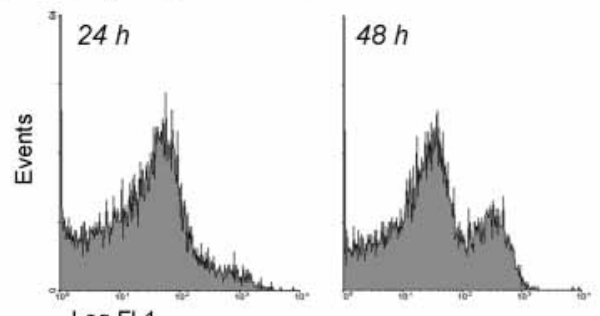

Log FL1

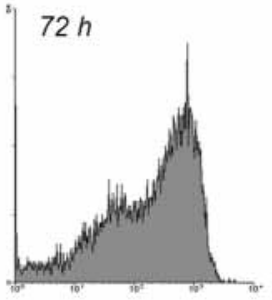

B Clopidogrel + 2MeSADP

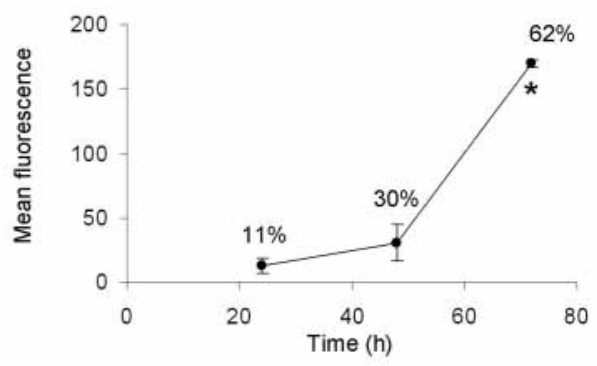

D Ticagrelor + 2MeSADP

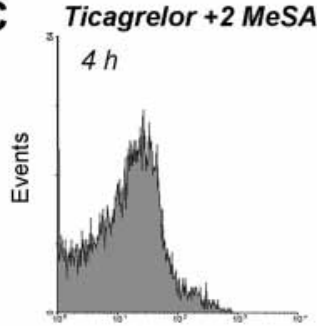

Log FL1
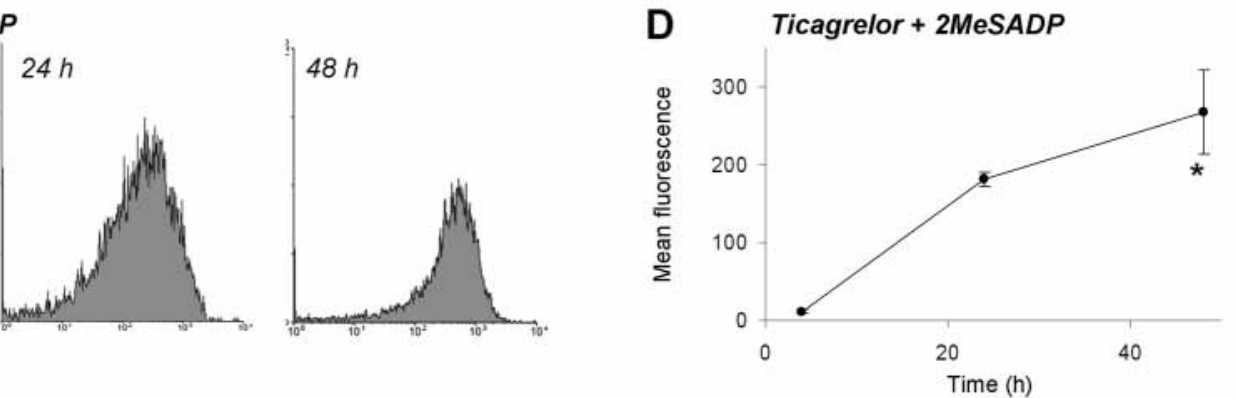

Figure 2: Reappearance of $\mathrm{P}_{2} \mathrm{Y}_{12}$-responsive platelets after rat treatment with clopidogrel or ticagrelor. Rats were treated with a single dose of clopidogrel or ticagrelor, as described for Figure 1. Blood samples and PRP were isolated after indicated times. Platelets in PRP were stimulated for 10 min with $20 \mu \mathrm{M}$ 2MeSADP; OG488-fibrinogen binding to platelets was assessed by flow cytometry. A, C) Representative histograms of OG488-fibrinogen binding after stimulation. B, D) Quantification of 0G488-fibrinogen binding to 2MeSADP-stimulated platelets. Percentage values indicate fractions of fibrinogen-positive platelets. Means \pm SE $(n=3-4) ;{ }^{*} p<0.05$ vs. earliest time point.
Figure 3: Retained $\mathrm{P}_{2} \mathrm{Y}_{12}$ non-responsiveness of platelets from clopidogrel-treated rats. Rats were treated for $24 \mathrm{~h}$ with a single clopidogrel dose or remained untreated (control). Mixtures of clopidogrel-treated and control PRP were prepared, and platelets (plts) were stimulated for 10 min with $20 \mu \mathrm{M} 2 \mathrm{MeS}$ ADP. Binding of OG488-fibrinogen to platelets was assessed by flow cytometry. A) Representative histograms; B) Fractions of OG488-fibrinogen-binding platelets; parameters of regression analysis indicated. Means $\pm S E(n=3)$.

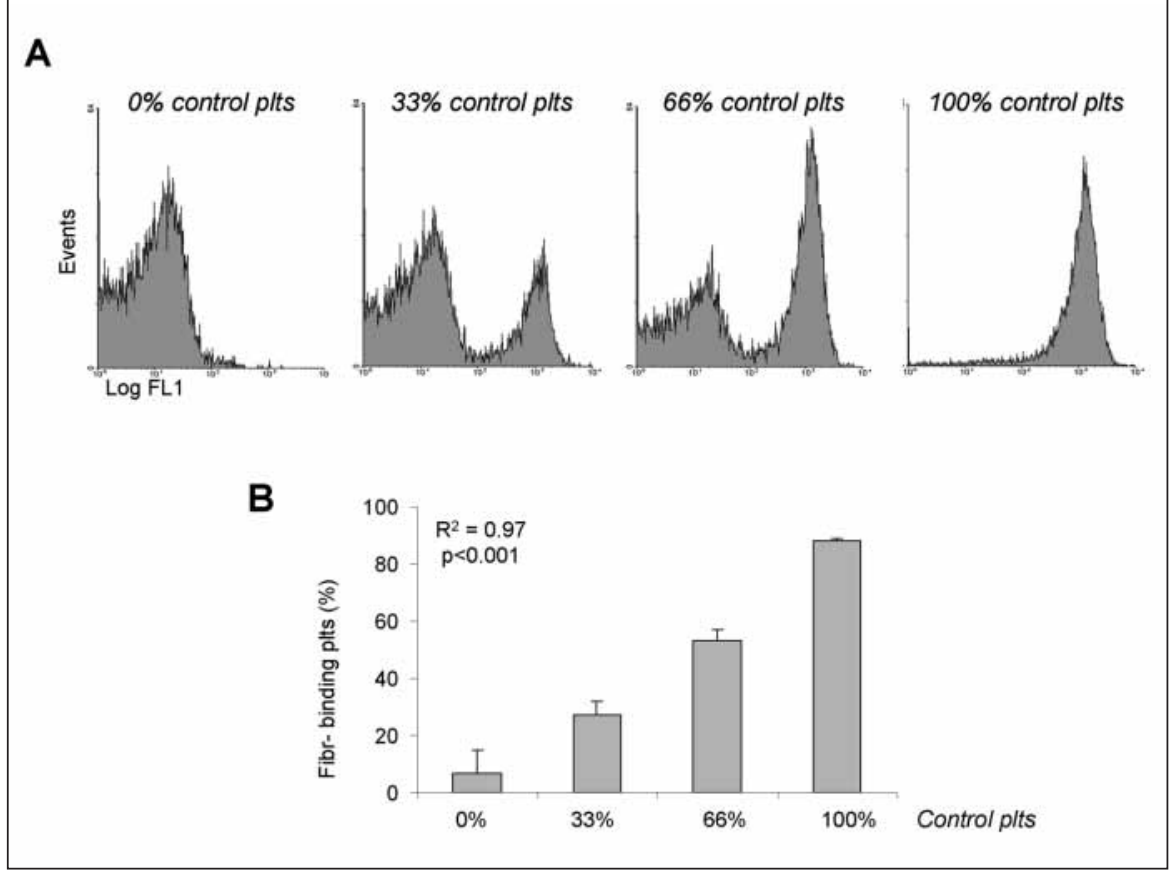




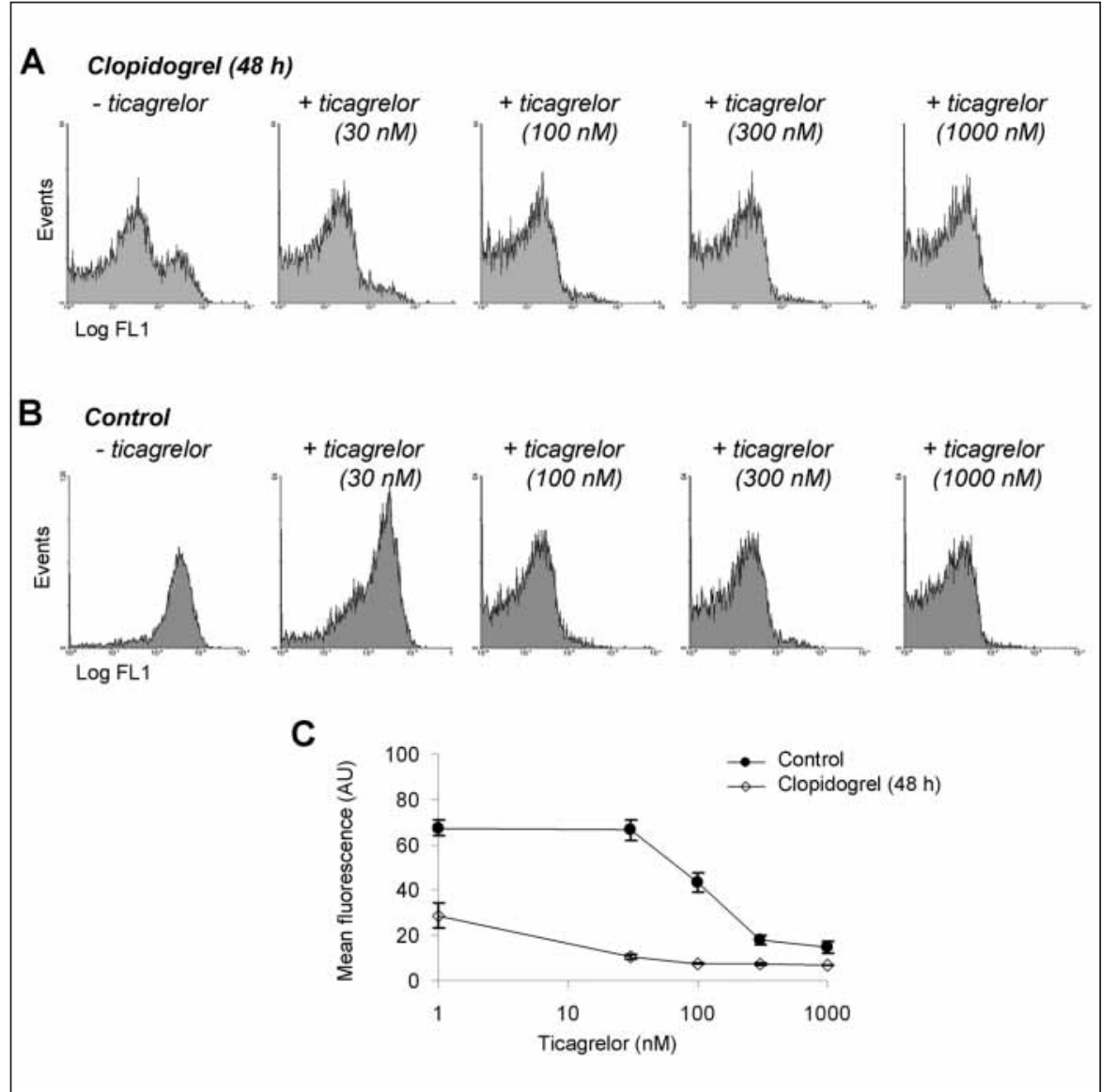

Figure 4: Effect of ticagrelor on $\mathrm{P}_{2} \mathrm{Y}_{12}$ responsiveness of clopidogrel-treated and control rats. Rats were remained untreated (control) or were treated for $48 \mathrm{~h}$ with a single clopidogrel dose. Samples of PRP were incubated with ticagrelor $(30-1,000 \mathrm{nM})$, and stimulated for 10 min with $20 \mu \mathrm{M}$ 2MeSADP. Binding of OG488-fibrinogen to platelets was assessed by flow cytometry. A, B) Representative histograms of FITC-fibrinogen binding to platelets from clopidogrel-treated (A) or control (B) rats. C) Quantification of fibrinogen binding with increasing doses of ticagrelor. Means $\pm \mathrm{SE}$ $(n=3)$.

\section{Differences in whole blood platelet aggregation and thrombus formation after recovery from $\mathrm{P}_{2} \mathrm{Y}_{12}$ inhibition with either clopidogrel or ticagrelor}

Whole blood platelet aggregation was measured to determine the functional consequences of $\mathrm{P}_{2} \mathrm{Y}_{12}$ receptor blockade after clopidogrel or ticagrelor application. Whole blood impedance aggregation studies revealed full inhibition of ADP-induced aggregation at $24 \mathrm{~h}$ post clopidogrel dosing, with only slight recovery $48 \mathrm{~h}$ post dosing ( Fig. 5A). At 4 or $18 \mathrm{~h}$ after ticagrelor treatment, whole blood platelet aggregation remained completely inhibited. Essentially similar results were obtained by measuring aggregation in whole blood by analysis of the residual platelet count. In blood from control rats, $\mathrm{ADP}$ caused a transient reduction in platelet count, which was nearly complete at $1-2 \mathrm{~min}$ ( Fig. 5B). At $24 \mathrm{~h}$ after clopidogrel or $4 \mathrm{~h}$ after ticagrelor administration, the ADP-induced platelet aggregation was completely inhibited. However, $48 \mathrm{~h}$ after clopidogrel or $18 \mathrm{~h}$ after ticagrelor, ADP-induced aggregation was partly recovered ( $\sim 50 \%$ of control at $1 \mathrm{~min}$ after ADP).

Blood samples from the same clopidogrel- and ticagrelortreated rats were used to measure thrombus formation on collagen under high shear flow conditions. In blood taken shortly after each treatment ( 24 and $4 \mathrm{~h}$, respectively), brightfield images indicated a strong decrease in platelet deposition on collagen in comparison to blood from untreated control rats ( Fig. 6A, B). Also, the size of the platelet aggregates was markedly reduced after each treatment, so that only small aggregates and single platelets were left on the collagen surface ( Fig. 6C). In contrast, at longer times after treatment ( $48 \mathrm{~h}$ clopidogrel and $18 \mathrm{~h}$ ticagrelor), the two $\mathrm{P} \mathrm{Y}_{12}$ antagonists markedly differed in effects on thrombus formation, despite the similarity in effects on whole blood platelet aggregation. The blood from ticagrelor-treated rats (partly blocked $\mathrm{P}_{12} \mathrm{Y}_{12}$ receptors on all platelets) showed a marked reduction in platelet deposition and aggregate size, whereas the blood from clopidogrel-treated rats (mix of $\mathrm{P}_{2} \mathrm{Y}_{12}$ blocked and unblocked platelets) gave normal thrombus formation with large platelet aggregates ( Fig. 6A-C). The higher platelet deposition and larger aggregate size after clopidogrel treatment was a consequence of increased platelet adhesion during flow.

To further study the thrombogenic effect of unprotected platelets in clopidogrel-treated rats, blood and isolated platelets were used from rats treated for $24 \mathrm{~h}$ with a single clopidogrel dose or from untreated, control rats. The platelets isolated from clopidogrel-treated or control rats were labelled with CFSE, and then added ( $20 \%$ of count) to the blood from clopidogrel-treated rats. In separate experiments, it was checked that the labelling of platelets with CFSE did not affect 2MeSADP-induced platelet aggregation, nor the ability of ticagrelor to inhibit this response (see -Suppl. Fig. 1 available online at www.thrombosis-online.com). Fluorescence loading was equally well for the control and clopido- 
grel platelets (data not shown). Collagen-dependent thrombus formation was studied by flowing blood samples at a high shear rate of 1,000 s-1 over a collagen surface. Markedly, addition of 20\% CSFE-labelled control platelets to clopidogrel blood resulted in significantly higher platelet deposition and in larger aggregates than addition of $20 \%$ CFSE-labelled clopidogrel platelets ( Fig. $7 \mathrm{~A}, \mathrm{~B})$. Continuous recording of fluorescence images during the flow experiment indicated that the deposition rate of CFSE-labelled control platelets was two times higher than that of CFSE-labelled clopidogrel platelets ( Fig. 7C). Experiments with control blood confirmed the high reactivity of CFSE-labelled control platelets in thrombus formation ( Fig. 7A-C).

For quantitative comparison, recorded confocal fluorescence and brightfield images from the same experiments were analysed after $4 \mathrm{~min}$ of blood flow. Calculation of the ratio of surface area coverage of fluorescent/total platelets gave values of $19 \pm 4 \%$ and $24 \pm 3 \%$ (mean \pm SE, $n=3$ ) for the combinations of CFSE-labelled clopidogrel platelets/clopidogrel blood and CFSE-labelled control platelets/control blood, respectively. Hence, in either case, the relative area coverage (19-24\%) reflected the fractions of added CFSE-labelled platelets (20\%). On the other hand, importantly, this ratio was significantly higher when $20 \%$ CFSE-labelled control platelets were added to clopidogrel blood, reaching $40 \pm 8 \%$ $(\mathrm{p}<0.05)$, pointing to a preferential incorporation of the $\mathrm{P} 2 \mathrm{Y}_{12}$-responsive control platelets into thrombi formed by clopidogreltreated platelets.

\section{Discussion}

In this study, we have observed important differences in functional consequences of rat treatment with a single, high dose of clopidogrel, an irreversible antagonist of the $\mathrm{P}_{2} \mathrm{Y}_{12}$ receptor, and rat treatment with the reversibly binding $\mathrm{P}_{2} \mathrm{Y}_{12}$ antagonist, ticagrelor. Shortly after treatment, both clopidogrel (24 h) and ticagrelor (4 h) completely prevented $2 \mathrm{MeSADP}$ induced fibrinogen binding, which indicated effective blockade of $\mathrm{P} 2 \mathrm{Y}_{12}$-mediated $\alpha_{\mathrm{IIb}} \beta_{3}$ activation. At longer times after treatment, a gradual recovery of this response was seen in ticagrelor-treated blood, which is most likely due to its gradually declining concentration in the rat plasma, similarly as was shown in human plasma (23). However, in blood from clopidogrel-treated rats, two platelet populations were recognised. One population of platelets was still protected from ADP-induced integrin activation, while other platelets appeared to be fully responsive. The distinct properties of these two platelet populations were confirmed by flow cytometric analysis of mixed blood samples from clopidogrel-treated and control rats. Interestingly, in vitro addition of ticagrelor to the blood from clopidogrel-treated rats, caused concentration-dependent inhibition of $\mathrm{P}_{2} \mathrm{Y}_{12}$ receptors of the responsive platelet population. The fact that only one platelet population was seen after treatment with ticagrelor, at any time point, is in agreement with the fully reversible binding mechanism of this $\mathrm{P}_{2} \mathrm{Y}_{12}$ antagonist. Taken together, these findings indicated that new, juvenile platelets formed after clopidogrel treat-

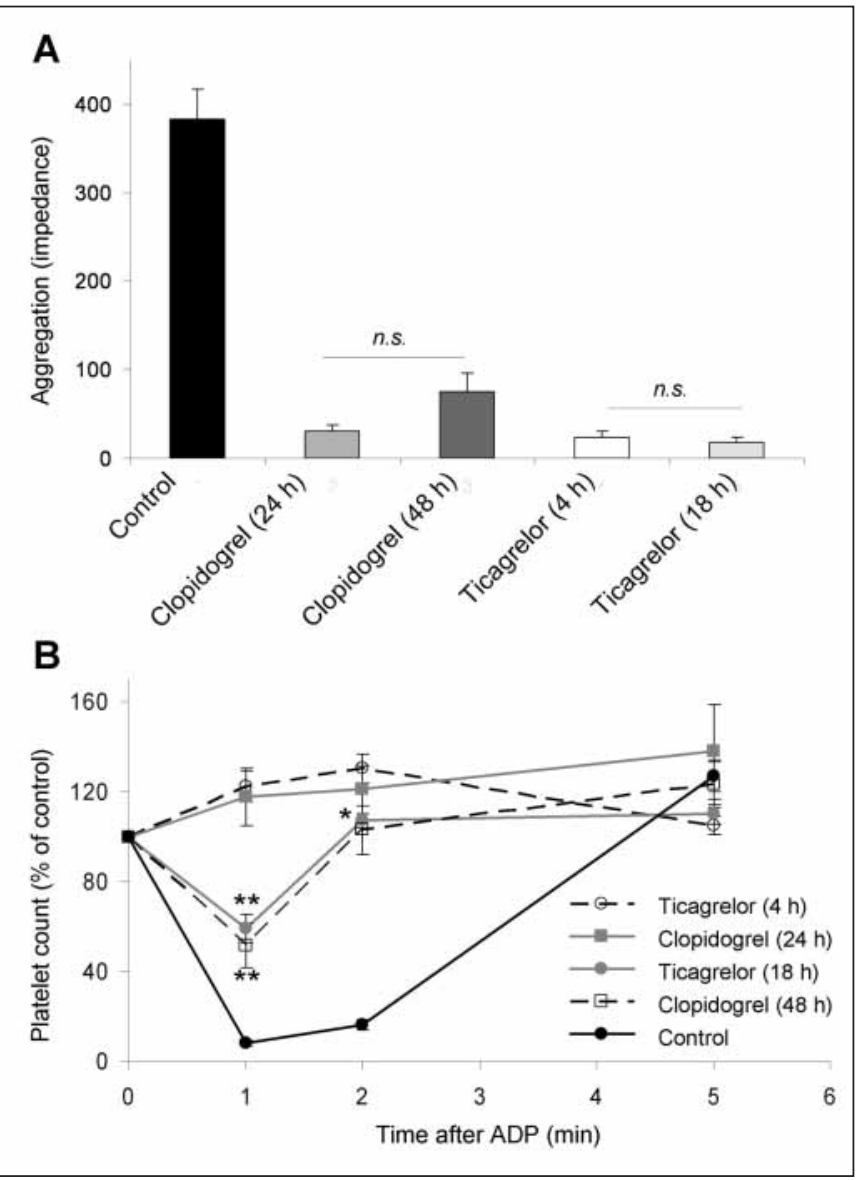

Figure 5: Effect of rat treatment with clopidogrel or ticagrelor on ADP-induced platelet aggregation in whole blood. Rats remained untreated (control) or received clopidogrel or ticagrelor, as described for Figure 1. Blood was obtained from different rats after treatment at indicated time points, and stimulated with $6.4 \mu \mathrm{M}$ ADP. A) Maximal aggregation response to $A D P$, as determined by whole blood impedance aggregometry $(n=5-8)$. (B) Residual platelet count in whole blood at indicated times after ADP stimulation ( $n=6-8)$. Means $\pm S E ;{ }^{*} p<0.01$, ${ }^{* *} p<0.001$ vs. early time point.

ment, expose active $\mathrm{P} 2 \mathrm{Y}_{12}$ receptors that are fully sensitive to reversible $\mathrm{P}_{2} \mathrm{Y}_{12}$ antagonism.

Whole blood aggregation studies were performed to investigate the functional consequences of the formation of the unprotected platelet population after clopidogrel intake. Measurement of the residual platelet count in whole blood revealed a comparable degree of inhibition of ADP-induced aggregation at $24 \mathrm{~h}$ after clopidogrel and $4 \mathrm{~h}$ after ticagrelor $(>80 \%)$. This inhibition decreased after longer time points. Also whole blood impedance aggregometry showed a similar degree of inhibition after clopidogrel or ticagrelor. Hence, both whole blood aggregation assays detected no difference between clopidogrel or ticagrelor intake, in contrast to the differences seen in flow cytometry.

In contrast, thrombus formation on collagen under flow conditions, where the release of autocrine ADP is a limiting factor for aggregate build-up $(28,29)$, was increased by the appearance of 
A

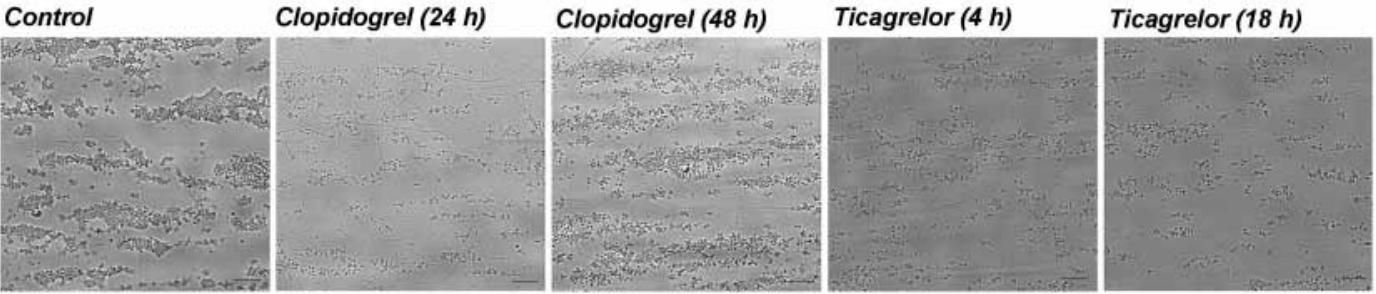

B

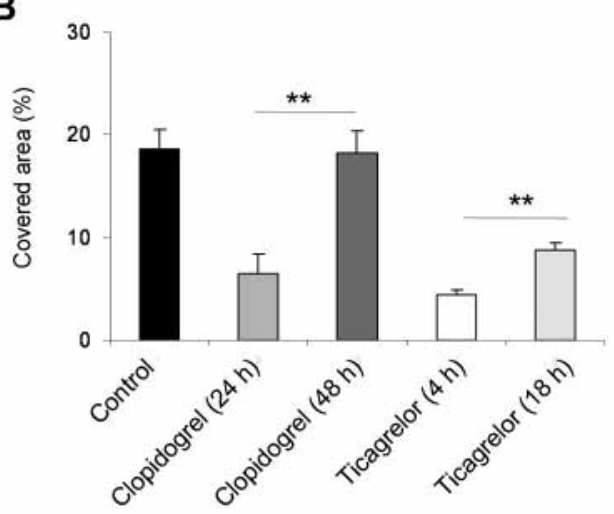

Figure 6: Effect of rat treatment with clopidogrel or ticagrelor on collagen-dependent thrombus formation under flow. Rats were untreated (control) or treated with clopidogrel or ticagrelor, as described for Figure 1. PPACK-anticoagulated blood was obtained at indicated times after treatment, and perfused over collagen for $4 \min$ at $1,000 \mathrm{~s}^{-1}$. A) Representative
C

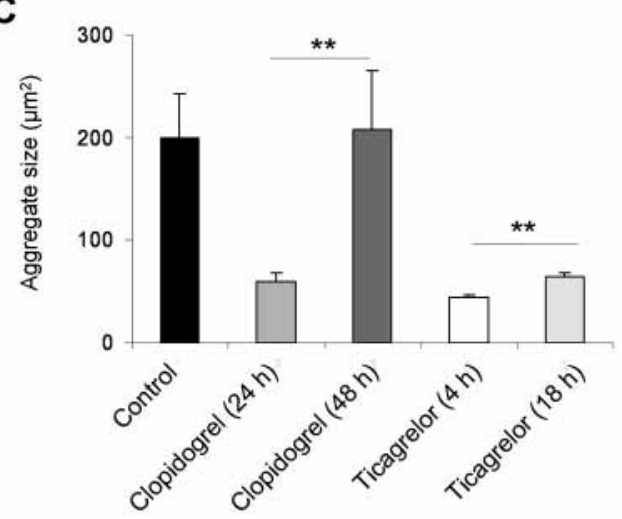

platelets with active $\mathrm{P} 2 \mathrm{Y}_{12}$ receptors at $48 \mathrm{~h}$ vs. $24 \mathrm{~h}$ after clopidogrel treatment. Platelet aggregates formed on the collagen surface were more abundant and larger in size, as compared to those formed in blood from rats treated with ticagrelor. A similar increase in thrombus formation was observed, when control platelets were added in vitro to blood collected at $24 \mathrm{~h}$ after clopidogrel treatment. It is concluded that, in clopidogrel-treated blood, the juvenile, newly formed platelets preferably incorporate into a growing thrombus by effectively responding to released ADP and activate their integrins. These incorporated platelets promote further platelet activation by release of autocrine platelet activators like ATP, Gas6 and thromboxane $A_{2}(30,31)$. Hence, it appears that in flow chambers it is the continuous flow of new blood which results in progressive accumulation of juvenile platelets, in contrast to the situation with platelet aggregation assays in closed systems. The latter assays do not seem to discriminate between partial inhibition of all platelets (ticagrelor) and no inhibition of a platelet fraction (clopidogrel).

The variability in degree of platelet inhibition observed with clopidogrel treatment was shown to correlate with the extent of $\mathrm{P}_{12} \mathrm{Y}_{12}$ receptor occupancy (32). This so-called clopidogrel resistance can have various causes, in particular a reduced efficacy of the two-step conversion of clopidogrel into the active metabolite in the liver $(10,33)$. Likely, also inter-individual differences in platelet phase-contrast images after 4 min of flow (bars, $10 \mu \mathrm{m})$. B) Surface area coverage of thrombi after flow. C) Average size of platelet aggregates on coverslip as determined by morphometric image analysis. Means $\pm \mathrm{SE}$ $(n=5-8) ;{ }^{*} p<0.001$ compared to early time point.

turnover rate may contribute to the variable drug response. To demonstrate this, it will be important to screen patients taking

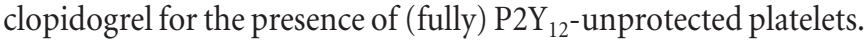
In the recent RESPOND study, it was shown that the antiplatelet effect of ticagrelor is similar in clopidogrel responders and non-responders in protecting against $\mathrm{P} 2 \mathrm{Y}_{12}$-induced platelet activation $(16,34)$. This is in agreement with the present data with rat platelets, where we find that ticagrelor inhibits juvenile, unprotected platelets in clopidogrel-treated rats.

Clinical studies have unequivocally demonstrated the efficacy of clopidogrel as an antithrombotic drug, although partial non-responsiveness is a relatively frequent phenomenon $(3,9)$. In current literature no data is available concerning clopidogrel resistance and the offset of the anti-platelet effect. Since platelet turnover in humans ( $8-10$ days) is slower than in rodents ( $3-5$ days), the formation of new platelets in between the intake of two capsules of clopidogrel is expected to be relatively low. Nonetheless, the appearance of juvenile, unprotected platelets can be of importance, when for example platelet turnover is high, clopidogrel treatment is stopped, or the treatment regimen is not followed correctly. Accordingly, the mechanism discovered in this paper may provide another explanation for the increased platelet reactivity and the clustering of adverse clinical events after cessation of clopidogrel in patients receiving drug-eluting stents $(11,12)$. 


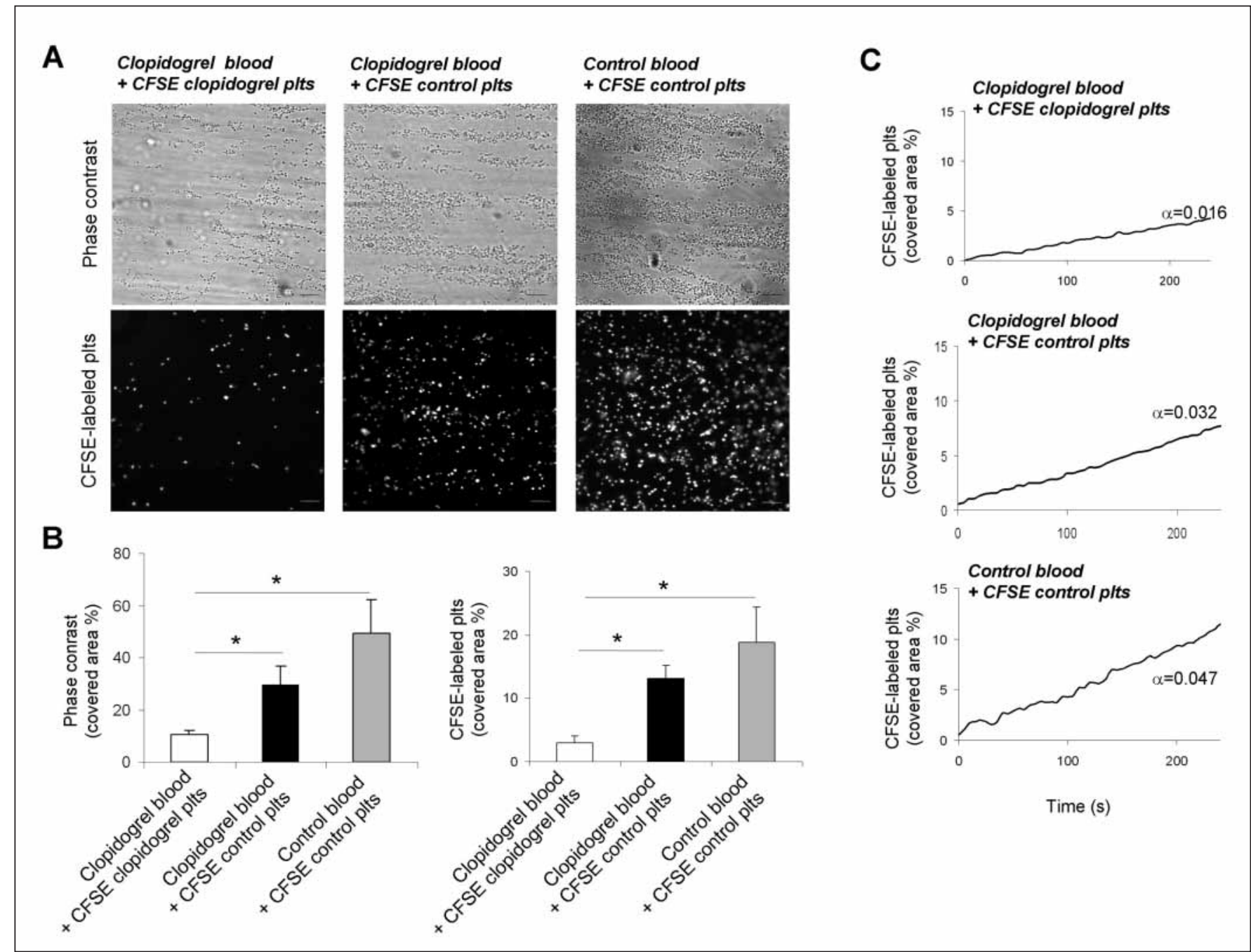

Figure 7: Normal contribution to thrombus formation of control platelets after clopidogrel treatment. Rats were untreated (control) or treated for $24 \mathrm{~h}$ with a single dose of clopidogrel $(200 \mathrm{mg} / \mathrm{kg})$. CFSE-labelled platelets (plts) from clopidogrel-treated and control rats were prepared, washed, and added at $20 \%$ of count to the respective blood samples. PPACKanticoagulated blood containing CFSE-labelled platelets was perfused over collagen for $4 \mathrm{~min}$ at $1,000 \mathrm{~s}^{-1}$, followed by wash. A) Representative phase- contrast and fluorescence images captured after 4 min of flow (bars, $10 \mu \mathrm{m}$ ). B) Total area coverage of total thrombi and of CFSE-labelled platelets after flow. Means \pm SE $(n=3-4) ;{ }^{*} p<0.05$. C) Time series were recorded of CFSE fluorescence $(0.2 \mathrm{~Hz})$ during perfusion of blood over collagen, and images analysed for area covered by fluorescently labelled platelets. Representative traces are shown with curve slope value $\alpha$.
In summary, these findings reveal a difference in platelet function recovery after treatment with an irreversible (clopidogrel) or a reversible (ticagrelor) $\mathrm{P}_{2} \mathrm{Y}_{12}$ antagonist. After recovery from treatment with clopidogrel, a mixed platelet population of fully protected and unprotected platelets appears. After ticagrelor treatment, all platelets, including the newly formed ones, only gradually lose protection over time. Furthermore, the functional recovery of unprotected platelets appears to be masked in closed-system platelet aggregation tests, but becomes apparent under flow-perfusion conditions, where thrombus formation after recovery from clopidogrel treatment increases in a time-dependent manner. This formation of fully responsive platelets at later time points after clopidogrel treatment may be of clinical relevance.

\section{Acknowledgements}

We thank Dr. S. Nylander and M. Kjerrulf for discussions and experimental assistance.

\section{Conflict of interest}

E.N. and J.J.J.v.G. are employees of Astra-Zeneca R\&D, Mölndal, Sweden. Part of this study was financially supported by AstraZeneca. None of the other authors declare any conflict of interest. 


\section{What is known about this topic?}

- Platelet $P 2 Y_{12}$ receptors play an important role in arterial thrombus formation.

- Both irreversibly (clopidogrel) and reversibly binding (ticagrelor, AZD6140) $P 2 Y_{12}$ antagonists are used clinically. The physiological consequences of the differences in action mechanism of irreversible and reversible antagonists during recovery are unknown.

\section{What does this paper add?}

- Recovery of rat platelet function after clopidogrel but not ticagrelor occurs by production of fully active, juvenile platelets.

- This difference in recovered function is masked by conventional platelet aggregation methods, but is revealed by thrombus formation measurement under flow.

- Juvenile rat platelets formed after stopping clopidogrel treatment promoted thrombus formation.

\section{References}

1. Offermanns S. Activation of platelet function through $G$ protein-coupled receptors. Circ Res 2006; 99: 1293-1304.

2. Savi $\mathrm{P}$, Herbert JM. Clopidogrel and ticlopidine: $\mathrm{P}_{2} \mathrm{Y}_{12}$ adenosine diphosphate-receptor antagonists for the prevention of atherothrombosis. Semin Thromb Hemost 2005; 31: 174-183.

3. Gurbel PA, Tantry US. Drug insight: Clopidogrel non-responsiveness. Nat Clin Pract Cardiovasc Med 2006; 3: 387-395.

4. Committee CS. A randomised, blinded, trial of clopidogrel versus aspirin in patients at risk of ischaemic events (CAPRIE). CAPRIE Steering Committee. Lancet 1996; 348: 1329-1339.

5. Fox KA, Mehta SR, Peters R, et al. Benefits and risks of the combination of clopidogrel and aspirin in patients undergoing surgical revascularization for non-STelevation acute coronary syndrome: the Clopidogrel in Unstable angina to prevent Recurrent ischemic Events (CURE) Trial. Circulation 2004; 110: 1202-1208.

6. Kazui M, Nishiya Y, Ishizuka T, et al. Identification of the human cytochrome P450 enzymes involved in the two oxidative steps in the bioactivation of clopidogrel to its pharmacologically active metabolite. Drug Metab Dispos 2010; 38 92-99.

7. Bouman HJ, Schomig E, van Werkum JW, et al. Paraoxonase-1 is a major determinant of clopidogrel efficacy. Nat Med 2011; 17: 110-116.

8. Wallentin L, Varenhorst C, James S, et al. Prasugrel achieves greater and faster $\mathrm{P} 2 \mathrm{Y}_{12}$ receptor-mediated platelet inhibition than clopidogrel due to more efficient generation of its active metabolite in aspirin-treated patients with coronary artery disease. Eur Heart J 2008; 29: 21-30.

9. Cattaneo $\mathrm{M}$. The platelet $\mathrm{P}_{2} \mathrm{Y}_{12}$ receptor for adenosine diphosphate: congenital and drug-induced defects. Blood 2011; 117: 2102-2012.

10. Smith SM, Judge HM, Peters G, et al. Common sequence variations in the $\mathrm{P}_{2} \mathrm{Y}_{12}$ and CYP3A5 genes do not explain the variability in the inhibitory effects of clopidogrel therapy. Platelets 2006; 17: 250-258.

11. Mylotte D, Peace AJ, Tedesco AT, et al. Clopidogrel discontinuation and platelet reactivity following coronary stenting. J Thromb Haemost 2011; 9: 24-32.

12. Sambu N, Warner T, Curzen N. Clopidogrel withdrawal: is there a „rebound“ phenomenon? Thromb Haemost 2011; 105: 211-220.

13. Van Giezen JJJ, Nilsson L, Berntsson P, et al. Ticagrelor binds to human $\mathrm{P}_{2} \mathrm{Y}_{12}$ independently from ADP but antagonizes ADP-induced receptor signaling and platelet aggregation. J Thromb Haemost 2009; 7: 1556-1565.

14. Cannon CP, Husted S, Harrington RA, et al. Safety, tolerability, and initial efficacy of AZD6140, the first reversible oral adenosine diphosphate receptor antagonist, compared with clopidogrel, in patients with non-ST-segment elevation acute coronary syndrome: primary results of the DISPERSE-2 trial. J Am Coll Cardiol 2007; 50: 1844-1851.

15. Cannon CP, Harrington RA, James S, et al. Comparison of ticagrelor with clopidogrel in patients with a planned invasive strategy for acute coronary syndromes (PLATO): a randomised double-blind study. Lancet 2010; 375: 283-293.

16. Gurbel PA, Bliden KP, Butler K, et al. Response to ticagrelor in clopidogrel nonresponders and responders and effect of switching therapies: the RESPOND study. Circulation 2010; 121: 1188-1199.

17. Gurbel PA, Bliden KP, Butler K, et al. Randomized double-blind assessment of the ONSET and OFFSET of the antiplatelet effects of ticagrelor versus clopidogrel in patients with stable coronary artery disease: the ONSET/OFFSET study. Circulation 2009; 120: 2577-2585.

18. Van Giezen JJ. Optimizing platelet inhibition. Eur Heart J 2008; 10: D23-29.

19. Heemskerk JW, Kuijpers MJ, Munnix IC, et al. Platelet collagen receptors and coagulation. A characteristic platelet response as possible target for antithrombotic treatment. Trends Cardiovasc Med 2005; 15: 86-92.

20. Munnix IC, Strehl A, Kuijpers MJ, et al. The glycoprotein VI-phospholipase C $\gamma 2$ signaling pathway controls collagen- and tissue factor-induced thrombus formation in vitro and in vivo. Atheroscler Thromb Vasc Biol 2005; 25: 2673-2678.

21. Sigfridsson K, Björkman JA, Skantze P, et al. Usefulness of a nanoparticle formulation to investigate some hemodynamic parameters of a poorly soluble compound. J Pharm Sci 2011; 100: 2194-2202.

22. Van Giezen JJ, Berntsson P, Zachrisson H, et al. Comparison of ticagrelor and thienopyridine $\mathrm{P}_{2} \mathrm{Y}_{12}$ binding characteristics and antithrombotic and bleeding effects in rat and dog models of thrombosis/hemostasis. Thromb Res 2009; 124: $565-571$.

23. Teng R, Butler K. Pharmacokinetics, pharmacodynamics, tolerability and safety of single ascending doses of ticagrelor, a reversibly binding oral $\mathrm{P} 2 \mathrm{Y}_{12}$ receptor antagonist, in healthy subjects. Eur J Clin Pharmacol 2010; 66: 487-496.

24. Bannerman R. The mouse in biomedical research. New York 1983; Academic Press.

25. Sibbing D, Braun S, Jawansky S, et al. Assessment of ADP-induced platelet aggregation with light transmission aggregometry and multiple electrode platelet aggregometry before and after clopidogrel treatment. Thromb Haemost 2008; 99: $121-126$.

26. Storey RF, May JA, Heptinstall S. Potentiation of platelet aggregation by heparin in human whole blood is attenuated by $\mathrm{P}_{2} \mathrm{Y}_{12}$ and $\mathrm{P} 2 \mathrm{Y}_{1}$ antagonists but not aspirin. Thromb Res 2005; 115: 301-307.

27. Kuijpers MJ, Gilio K, Reitsma S, et al. Complementary roles of platelets and coagulation in thrombus formation on plaques acutely ruptured by targeted ultrasound treatment: a novel intravital model. J Thromb Haemost 2009; 7: 152-161.

28. Lecut C, Schoolmeester A, Kuijpers MJ, et al. Principal role of glycoprotein VI in $\alpha_{2} \beta_{1}$ and $\alpha_{\text {II }} \beta_{3}$ activation during collagen-induced thrombus formation. Arterioscler Thromb Vasc Biol 2004; 24: 1727-1733.

29. Nergiz-Unal R, Cosemans JM, Feijge MA, et al. Stabilizing role of platelet $\mathrm{P} 2 \mathrm{Y}_{12}$ receptors in shear-dependent thrombus formation on ruptured plaques. Plos One 2010; 5: e10130.

30. Cosemans JM, van Kruchten R, Olieslagers S, et al. Potentiating role of Gas6 and TAM receptors in human and murine platelet activation and thrombus stabilization. J Thromb Haemost 2010; 8: 1797-1808.

31. Brass L. Fifty (or more) ways to leave your platelets (in a thrombus). Arterioscler Thromb Vasc Biol 2004; 24: 989-991.

32. Bal Dit Sollier C, Berge N, Boval B, et al. Functional variability of platelet response to clopidogrel correlates with $\mathrm{P}_{2} \mathrm{Y}_{12}$ receptor occupancy. Thromb Haemost 2009; 101: 116-122.

33. Patrono C. The $\mathrm{P}_{2} \mathrm{Y}_{12}$ receptor: no active metabolite, no party. Nat Rev Cardiol 2009; 6: 271-272.

34. Storey RF, Husted S, Harrington RA, et al. Inhibition of platelet aggregation by AZD6140, a reversible oral $\mathrm{P} 2 \mathrm{Y}_{12}$ receptor antagonist, compared with clopidogrel in patients with acute coronary syndromes. J Am Coll Cardiol 2007; 50: 1852-1856. 